\title{
A di-O-dihydrogeranylgeranyl glycerol from Thermococcus S 557, a novel ether lipid, and likely intermediate in the biosynthesis of diethers in Archæa
}

\author{
Isabelle Gonthier ${ }^{\mathrm{a}}$, Marie-Noëlle Rager ${ }^{\mathrm{b}}$, Pierre Metzger ${ }^{\mathrm{a}}{ }^{ }$, Jean Guezennec ${ }^{\mathrm{c}}$ and \\ Claude Largeau ${ }^{\mathrm{a}}$
}

${ }^{a}$ CNRS UMR 7573, Ecole Nationale Supérieure de Chimie de Paris, 11 Rue P. et M. Curie, 75231, Paris cedex 05, France

${ }^{\text {b }}$ Service RMN, CNRS UMR 7576, Ecole Nationale Supérieure de Chimie de Paris, 11 Rue P. et M. Curie, 75231, Paris cedex 05, France

' IFREMER, 29280, Plouzané, France

*: Corresponding author : Tel.: +33-144276717; fax: +33-143257975 pgmetzg@ext.jussieu.fr

\begin{abstract}
The lipids of a deep-sea hydrothermal vent archæon, Thermococcus S 557, were isolated, purified and structurally determined. Based on acid methanolysis and spectroscopic studies, the polar lipids were shown to comprise diphytanyl glycerol and dibiphytanyl diglycerol, typical membrane lipids of Archæa. From the neutral lipids, 2,3-di-O-dihydro-14,15-geranylgeranyl glycerol was isolated. This novel ether lipid is, very likely, a close intermediate in the biosynthesis of diphytanyl glycerol diether in Archæa.
\end{abstract}

Keywords: Archæa; Thermococcus sp; novel glycerol diether lipid; NMR; mass spectrometry 


\title{
A di-O-dihydrogeranylgeranyl glycerol from Thermococcus S 557, novel ether lipid, likely intermediate in the biosynthesis of diethers in Archæa
}

\author{
Isabelle Gonthier, ${ }^{\mathrm{a}}$ Marie-Noëlle Rager, ${ }^{\mathrm{b}}$ Pierre Metzger, ${ }^{\mathrm{a}}$ \\ Jean Guezennec $^{c}$ and Claude Largeau ${ }^{\mathrm{a}}$ \\ ${ }^{a}$ CNRS UMR 7573, Ecole Nationale Supérieure de Chimie de Paris, 11 Rue P. et M. Curie, 75231 Paris cedex 05 France \\ ${ }^{b}$ Service RMN, CNRS UMR 7576, Ecole Nationale Supérieure de Chimie de Paris, 11 Rue P. et M. Curie, \\ 75231 Paris cedex 05 France \\ 'IFREMER, 29280 Plouzané, France
}

\begin{abstract}
The lipids of a deep-sea hydrothermal vent archæon, Thermococcus S 557, were isolated, purified and structurally determined. Based on acid methanolysis and spectroscopic studies, the polar lipids were shown to comprise diphytanyl glycerol and dibiphytanyl diglycerol, typical membrane lipids of Archæa. From the neutral lipids, 2,3-di-O-dihydro-14,15-geranylgeranyl glycerol was isolated. This novel ether lipid is, very likely, a close intermediate in the biosynthesis of diphytanyl glycerol diether in Archæa.
\end{abstract}

Archæa are characterised by the presence of isopranyl glycerol ether lipids in their membranes, ${ }^{1}$ instead of acyl glycerol esters as in all other living organims. Two main ether lipids generally occur in Archæa: the diphytanyl glycerol diether (2,3-di-O-phytanyl-snglycerol, 1) and the dibiphytanyl diglycerol tetraether (2,3,2',3'-tetra-O-dibiphytanyl-di-snglycerol, 2). In this latter, the $\mathrm{C}_{40}$ dibiphytanyl chains derive from $\omega, \omega$ ' linkages of two $O$ phytanyl residues. Some other ether lipids, whose structures differ slightly from those of these two basic ethers, are known to occur in Archæa. For example, concerning the isopranoid moieties, one or two sesterterpanyl chain(s) may replace the phytanyl one(s) in some halophiles, ${ }^{2}$ substitution of a phytanyl chain by a hydroxyl group has been observed in a methanogen and in some methane-consuming Archæa, ${ }^{3}$ the formation of a macrocyclic diether by a head-to-head linkage of two phytanyl residues of a diether occurs in some methanogens, ${ }^{4}$ mid-chain $\mathrm{C}-\mathrm{C}$ linkage of two $\mathrm{C}_{40}$ units has been observed in the tetraethers of a hyperthermophilic methanogen ${ }^{5}$ and cyclopentane rings occur in the biphytanyl chains of the tetraethers in numerous thermoacidophiles. ${ }^{6}$ Continuing our investigation of lipids from Archæa originating from deep-sea hydrothermal vents, ${ }^{7}$ we now report the isolation and the structural identification of a novel glycerol diether from a Thermococcus species.

*Corresponding author. Tel.:+33-144276717; fax: +33-143257975; e-mail: pgmetzg@ext.jussieu.fr Keywords: Archæa; Thermococcus sp; novel glycerol diether lipid; NMR; mass spectrometry. 

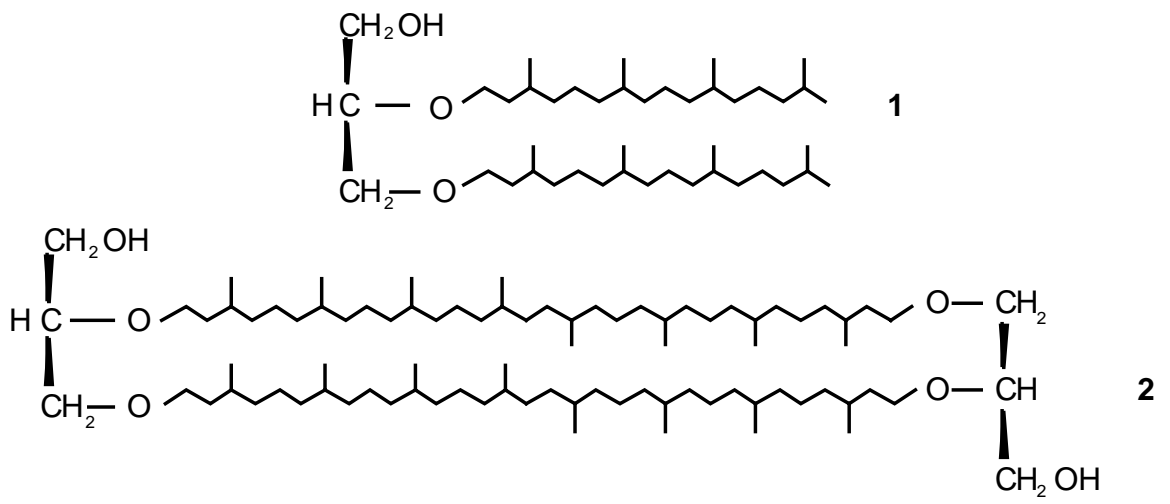

Thermococcus S 557 was cultured anaerobically under $\mathrm{N}_{2}$, in synthetic sea water, ${ }^{8}$ at $85^{\circ} \mathrm{C}$. Extraction of the lyophilized biomass (32 g) with $\mathrm{CH}_{2} \mathrm{Cl}_{2}-\mathrm{MeOH} 2: 1(500 \mathrm{ml} ; 2 \times 18 \mathrm{~h}$ ), furnished $2.2 \mathrm{~g}$ of crude extract, which was then fractionated by CC on silica gel $(70 \mathrm{~g})$. Neutral lipids were first eluted by $\mathrm{CHCl}_{3}(1200 \mathrm{ml})$. Polar lipids were recovered by elution with acetone-MeOH 9:1 (1375 ml) and then $\mathrm{MeOH}(350 \mathrm{ml})$. Acid methanolyses of the two concentrated polar fractions were performed in $1 \mathrm{~N} \mathrm{MeOH}-\mathrm{HCl}$ at $100^{\circ} \mathrm{C}$ for $18 \mathrm{~h}$ in closed tubes, the products extracted with $\mathrm{CH}_{2} \mathrm{Cl}_{2}$ and then diethyl ether. Separation by silica gel TLC of the methanolysate obtained from the methanol fraction (eluent heptane-diethyl ether$\mathrm{MeOH}$ 4:1:1) yielded the known diphytanyl glycerol diether $\mathbf{1},\left(\mathrm{C}_{43} \mathrm{H}_{88} \mathrm{O}_{3}\right)$, and dibiphytanyl diglycerol tetraether 2, $\left(\mathrm{C}_{86} \mathrm{H}_{172} \mathrm{O}_{6}\right)$. Additional amounts of $\mathbf{1}$ and $\mathbf{2}$ were obtained from the extracted biomass by acid methanolysis $(\mathrm{HCl} 1 \mathrm{~N})$ of the archæal residue, at $100^{\circ} \mathrm{C}$. On a whole, 1 and 2 were in the relative proportion 1:3 and accounted for $0.95 \%$ of the dry wt; no cyclopentane ring-containing tetraether was isolated. Neutral lipids were subjected to silica gel CC by elution with heptane containing increasing amounts of diethyl ether and the fraction eluted with pure diethyl ether was collected. Further purification of this fraction by silica gel TLC (eluent heptane-diethyl ether-MeOH 4:1:1), furnished compound 3 as a clear oil $\left(0.015 \%\right.$ of dry wt); $[\alpha]_{D}^{25}=+5$ (c. $\left.0.28, \mathrm{CHCl}_{3}\right)$.

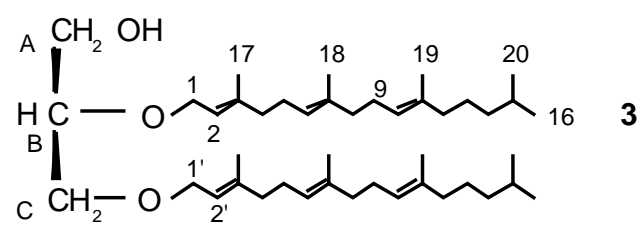

The HRFAB(magic bullet-NaI) mass spectrum of 3 displayed a $[\mathrm{M}+\mathrm{Na}]^{+}$adduct ion at $\mathrm{m} / \mathrm{z}$ 663.5685, corresponding to the molecular formula $\mathrm{C}_{43} \mathrm{H}_{76} \mathrm{O}_{3}\left([\mathrm{M}+\mathrm{Na}]^{+}\right.$calcd. 663.5692). The LRFAB(NBA/LiI+NaI) mass spectrum showed a base peak at $\mathrm{m} / \mathrm{z} 669.5$ for the adduct ion $\left[\mathrm{C}_{43} \mathrm{H}_{76} \mathrm{O}_{3}-\mathrm{H}+\mathrm{Na}+\mathrm{Li}\right]^{+}$(rel. int.: 100). A fragment ion at $\mathrm{m} / \mathrm{z} 379.4$ (rel. int.: 40) was assigned to $\left[\mathrm{M}-\mathrm{C}_{20} \mathrm{H}_{34} \mathrm{O}+\mathrm{Li}+\mathrm{Na}\right]^{+}$. These mass data suggested that $\mathbf{3}$ is a diether of glycerol comprising six degrees of unsaturation.

The characteristic absorption bands in the IR spectrum $\left(\mathrm{CCl}_{4}\right)$ were: $\mathrm{OH}\left(3580 \mathrm{~cm}^{-1}\right), \mathrm{CH}_{2}$ and $\mathrm{CH}_{3}\left(2940,2920,2860,2850\right.$ and $\left.1465 \mathrm{~cm}^{-1}\right)$, trisubstituted double bond $\left(1675\right.$ and $\left.820 \mathrm{~cm}^{-1}\right)$, $\left(\mathrm{CH}_{3}\right)_{2} \mathrm{C}\left(1380\right.$ and $\left.1365 \mathrm{~cm}^{-1}\right)$, C-O-C ether $\left(1095 \mathrm{~cm}^{-1}\right)$ and primary hydroxyl C-O (1040 $\left.\mathrm{cm}^{-1}\right)$.

The ${ }^{1} \mathrm{H}$ NMR spectrum of $\mathbf{3}$ showed three distinct resonance regions for olefinic and aliphatic protons and protons borne by carbons bound to oxygen atoms. In the $\mathrm{CHO}$ region, in addition to a poorly resolved resonance envelope at $\delta_{\mathrm{H}} 3.45-3.75$, the spectrum displayed three signals: 
two doublets of doublets at $\delta_{\mathrm{H}} 4.11$ and 4.17, for the two diastereotopic protons $\mathrm{H}-1$ and a doublet at $\delta_{\mathrm{H}} 4.01$ integrating for two protons, ascribed to the two protons $\mathrm{H}-1$ '. In the COSY spectrum, the connectivities observed with these signals allowed to assign the olefinic protons 2 and 2', exhibiting resonances at $\delta_{\mathrm{H}} 5.36$ and 5.33, respectively. The ${ }^{1} \mathrm{H}$ NMR spectrum indicated also the presence of two triplets, each integrating for two protons at $\delta_{\mathrm{H}} 5.09$ and 5.11. All these data established that 3 comprises six carbon-carbon double bonds. Four singlets resonating at $\delta_{\mathrm{H}} 1.67(3 \mathrm{H}), 1.66(3 \mathrm{H}), 1.60(6 \mathrm{H})$ and $1.58(6 \mathrm{H})$ were ascribed to vinylic methyl groups, while a doublet at $\delta_{\mathrm{H}} 0.86$ was assigned to four methyl groups bound to two methine carbons. Starting from these methine protons $\left(\delta_{\mathrm{H}}\right.$ at 1.52$)$, the COSY spectrum identified the protons of a terminal saturated moiety. This 2D spectrum and a subsequent HMBC experiment allowed the assignment of all the allylic protons (Table 1). These ${ }^{1} \mathrm{H}$ NMR data showed close similarities, except for the terminal saturated moieties, with those reported for 2,3-di-O-geranylgeranyl glycerol diether synthesized by incubation of geranylgeranyl diphosphate and glyceryl phosphate with a cell-free extract of Methanobacterium thermoautotrophicum. ${ }^{\text {9a }}$

Table 1.

${ }^{1} \mathrm{H}(400 \mathrm{MHz})$ and ${ }^{13} \mathrm{C}(100 \mathrm{MHz}) \mathrm{NMR}$ data of diether $3\left(\mathrm{CDCl}_{3}\right)$.

\begin{tabular}{|c|c|c|c|}
\hline Position & $\delta_{\mathrm{C}}$ & $\delta_{\mathrm{H}}$ (mult., $J \mathrm{~Hz}$ ) & $\mathrm{HMBC}^{\mathrm{a}}$ \\
\hline 1 & 66.6 & $\begin{array}{l}4.11(\mathrm{dd}, 6.6,11.8) \\
4.17(\mathrm{dd}, 6.6,11.8)\end{array}$ & $\mathrm{B}$ \\
\hline $1^{\prime}$ & 68.1 & $4.01(\mathrm{~d}, 6.8)$ & $\mathrm{C}$ \\
\hline 2 & 120.8 & $5.36(\mathrm{t}, 6.6)$ & $1,4,17$ \\
\hline $2^{\prime}$ & 120.6 & $5.33(\mathrm{t}, 6.8)$ & 1', 4', 17' \\
\hline $3,3^{\prime}$ & 140.7 & & $1,4,17$ \\
\hline $4,4^{\prime}$ & $39.8^{\mathrm{b}}$ & $2.08(\mathrm{~m})$ & 2,6 \\
\hline $5,5^{\prime}$ & $26.5,26.4$ & $2.05(\mathrm{~m})$ & $2,4,6$ \\
\hline $6,6^{\prime}$ & 123.9 & $5.09(\mathrm{t}, 7.1)$ & $4,8,18$ \\
\hline $7,7^{\prime}$ & 135.4 & & 8,18 \\
\hline $8,8^{\prime}$ & $39.7^{\mathrm{b}}$ & $2.00(\mathrm{~m})$ & 6,10 \\
\hline $9,9^{\prime}$ & 26.7 & $2.05(\mathrm{~m})$ & 8,10 \\
\hline $10,10^{\prime}$ & 124.0 & $5.11(\mathrm{t}, 6.2)$ & 12,19 \\
\hline $11,1^{\prime}$ & 135.4 & & 12,19 \\
\hline $12,12^{\prime}$ & 40.0 & $1.93(\mathrm{t}, 7.4)$ & $10,13,14,19$ \\
\hline 13,13 & 25.8 & $1.36(\mathrm{~m})$ & $10,12,14,15$ \\
\hline $14,14^{\prime}$ & 38.7 & $1.12(\mathrm{dt}, 9,6.8)$ & $12,13,15,16,20$ \\
\hline $15,15^{\prime}$ & 28.0 & $1.52(\mathrm{~m})$ & $13,14,16,20$ \\
\hline $16,16^{\prime}$ & 22.8 & $0.86(\mathrm{~d}, 6.6)$ & $14,15,20$ \\
\hline $17,1^{\prime}$ & 16.6 & $1.66(\mathrm{~s}), 1.67(\mathrm{~s})$ & 2,4 \\
\hline 18,18 & 16.1 & $1.60(\mathrm{~s})$ & 6,8 \\
\hline $19,19^{\prime}$ & 16.0 & $1.58(\mathrm{~s})$ & 10,12 \\
\hline $20,20^{\prime}$ & 22.7 & $0.86(\mathrm{~d}, 6.6)$ & $14,15,16$ \\
\hline A & 63.2 & $3.68(\mathrm{~m})$ & $\mathrm{B}, \mathrm{C}$ \\
\hline $\mathrm{B}$ & 78.4 & $3.58(\mathrm{~m})$ & A, C, 1 \\
\hline $\mathrm{C}$ & 70.1 & $3.53(\mathrm{~m})$ & A, B, 1' \\
\hline
\end{tabular}

${ }^{\text {a }}$ Protons correlating with carbon resonance. From positions 3,3' up to 20,20' only the correlations concerning carbons at positions 3-20 are reported.

${ }^{\mathrm{b}}$ Interchangeable values.

The DEPT 135 spectrum of 3 indicated signals due to methyl carbons at $\delta_{\mathrm{C}} 16.0,16.1,16.6$, 22.7 and 22.8, aliphatic methylene carbons at $\delta_{\mathrm{C}} 25.8,26.4,26.5,26.7,38.7,39.7,39.8,40.0$, methylene carbons bound to oxygen atoms at $\delta_{\mathrm{C}} 63.2,66.6,68.1$ and 70.1 , and methine 
carbons at $\delta_{\mathrm{C}} 28.0$ and 78.4. The ${ }^{13} \mathrm{C}$ NMR data confirmed also the presence of trisubstituted double bonds, including the C-2 = C-3 and C-2' = C-3' which showed well separated signals for the C-2 and C-2'. The chemical shifts of the allylic carbons at positions 4, 4', 8, 8', 12 and $12^{\prime}\left(\delta_{\mathrm{C}} 39.7,39.8\right.$ and 40.0$)$ established an $E$ configuration for the carbon-carbon double bonds. Furthermore, the HMBC spectrum confirmed the presence of a terminal isopranyl unit in each $\mathrm{C}_{20}$ unit. Moreover, the long range correlations observed on one hand from $\mathrm{H}_{\mathrm{B}}$ to $\mathrm{C}-1$ and from $\mathrm{H}-1$ to $\mathrm{C}_{B}$ and on the other hand from $\mathrm{H}_{\mathrm{C}}$ to $\mathrm{C}-1$ ' and from $\mathrm{H}-1$ ' to $\mathrm{C}_{C}$, demonstrated the ether linkage of two dihydrogeranylgeranyl units to a glycerol molecule, implicating one primary and the secondary carbons of this latter. Complete ${ }^{13} \mathrm{C}$ NMR chemical shift assignments of $\mathbf{3}$ are shown in Table 1. Furthermore, the optical rotation indicating that $\mathbf{3}$ is dextrorotatory established that this compound is a 2,3-sn-glycerol derivative. ${ }^{10}$ All the physical and spectroscopic data established that diether $\mathbf{3}$ is 2,3-di-O-dihydro-14,15geranylgeranyl-sn-glycerol.

Unsaturated ether lipids have been rarely isolated from Archæa so far. To the best of our knowledge, are only concerned some partially reduced tri-O-geranylgeranyl glycerol ethers synthesized by the thermoacidophile Caldariella acidophila, ${ }^{11}$ and those structures have not been fully determined, and a phytanyl, phytenyl diether isolated from some Halococcus species. ${ }^{12}$ The absence in the polar lipids (the core lipids) of Thermococcus S 557 of unsaturated ethers suggests that $\mathbf{3}$ could be an intermediate in the biosynthesis of ether lipids by Archæa. Indeed, Poulter and coworkers ${ }^{9}$ have shown that contrarily to what might be expected, isopranoid diethers do not arise from the coupling, via phosphate derivatives, of glycerol and phytanol but from coupling of glycerol and geranylgeraniol, the reduction of the unsaturations taking place in subsequent steps. ${ }^{13}$ The structure of the diether isolated in the present work strongly suggests that the reduction could begin at the head of the $\mathrm{C}_{20}$ isoprenoid, at least in the present species.

\section{Acknowledgements}

We are grateful to N. Morin (Ecole Normale Supérieure de Paris) for the FAB/MS analyses of the product.

\section{References and Notes}

1. (a) Kates, M.; Palameta, B.; Joo, C. N.; Kushner, D. J.; Gibbons, N. E. Biochemistry 1966, 5, 4092-4099, and references cited therein. (b) Tornabene, T. G.; Langworthy, T. A. Science 1979, 203, 51-53. (c) De Rosa, M; Gambacorta, A.; Nicolaus, B.; Bu’Lock, J.D. Phytochemistry 1980, 19, 821-825. (d) De Rosa, M; Gambacorta, A.; Gliozzi, A. Microbiol. Rev. 1986, 50, 70-80.

2. (a) De Rosa, M; Gambacorta, A.; Ross, H. N. M.; Grant, W. D.; Bu’Lock, J. D. J. Gen. Microbiol. 1982, 128, 343-348. (b) De Rosa, M; Gambacorta, A.; Nicolaus, B.; Grant, W. D. J. Gen. Microbiol. 1983, 129, $2333-2337$.

3. Ferrante, G.; Ekiel, I.; Patel, G. B.; Sprott, G. D. Biochim. Biophys. Acta 1988, 963, 173182. (b) Hinrichs, K.-U.; Hayes, J. M.; Sylva, S. P.; Brewer, P. G.; De Long, E. F. Nature 1999, 398, 802-805.

4. (a) Comita, P. B.; Gagosian, R. B. Science 1983, 222, 1329-1331. (b) Comita, P. B.; Gagosian, R. B.; Pang, H.; Costello, C. E. J. Biol. Chem. 1984, 259, 15234-15241. (c) Canganella, F.; Jones, W. J. Curr. Microbiol. 1994, 28, 299-306.

5. Morii, H.; Eguchi, T.; Nishihara, M.; Kakinuma, K.; König, H.; Koga, Y. Biochim. Biophys. Acta 1998, 1390, 339-345. 
6. (a) Langworthy, T. A. Biochim. Biophys. Acta 1977, 487, 37-50. (b) De Rosa, M; De Rosa, S.; Gambacorta, A.; Minale, L.; Bu'Lock, J. D. Phytochemistry 1977, 16, 19611965. (c) De Rosa, M; Gambacorta, A.; Nicolaus, B.; Chappe, B.; Albrecht, P. Biochim. Biophys. Acta 1983, 753, 249-256.

7. Lattuati, A.; Guezennec, J.; Metzger, P.; Largeau, C. Lipids 1998, 33, 319-326.

8. Composition of the medium in $\mathrm{g} / \mathrm{l}$ : sea salt (30), meat extract (10), sulphur (10), $\mathrm{Na}_{2} \mathrm{~S}, 7 \mathrm{H}_{2} \mathrm{O}(0.5)$; $\mathrm{pH}$ 7.1. After 6 h of growth the cells were harvested by centrifugation; yield: 1.9 g lyophilized cells/l.

9. (a) Zangh, D.-L.; Daniels, L.; Poulter, C. D. J. Am. Chem. Soc. 1990, 112, 1264-1265. (b) Poulter, C. D.; Aoki, T.; Daniels, L. J. Am. Chem. Soc. 1988, 110, 2620-2624. (c) Zangh, D.-L.; Poulter, C. D. J. Am. Chem. Soc. 1993, 115, 1270-1277.

10. Kates, M. In Ether Lipids; Snyder, F., Ed; Academic Press: New York, 1972.

11. (a) De Rosa, M.; De Rosa, S.; Gambacorta, A.; Bu'Lock, J. D. Phytochemistry 1976, 15 , 1995-1996. (b) This Archæon is presently known as Sulfolobus solfataricus: Zilling, W.; Stetter, K. O.; Wunderl, S.; Schula, W.; Priezz, H.; Scholz, I. Archiv. Microbiol. 1980, 125, 259-269.

12. Moldoveanu, N.; Kates, M.; Montero, C. G.; Ventosa, A. Biochim. Biophys. Acta 1990, 1046, 127-135.

13. (a) Moldoveanu, N.; Kates, M. Biochim. Biophys. Acta 1988, 960, 164-182. (b) Eguchi, T.; Takyo, H.; Morita, M.; Kakinuma, K.; Koga, Y. Chem. Comm. 2000, 1545-1546. 